\title{
ATMOSPHERIC CARBON SEQUESTRATION THROUGH AGROFORESTRY IN CHINA
}

\author{
XIAOKE WANG $\dagger$ and ZONGWEI FENG \\ Research Center for Eco-Environmental Sciences, P.O. Box 2871, Beijing 100085, \\ People's Republic of China
}

(Received 20 April 1994)

\begin{abstract}
Agroforestry is an important alternative to modern agriculture and forestry. It is useful in ameliorating environmental degradation, such as desertification and land erosion. During our study on biomass and productivity of agroforestry systems in the North China Plain, we found that agroforestry has a greater potential for storing and absorbing carbon from the atmosphere than has land cultivation. Furthermore, agroforestry systems produce timber and firewood that will bring profit to peasants and reduce the release of $\mathrm{CO}_{2}$ into the atmosphere.
\end{abstract}

\section{INTRODUCTION}

Concern about global warming has raised awareness that forest harvest can reduce carbon release by sequestering carbon and by substituting for fossil fuels. ${ }^{1}$ Efforts have been made to estimate the amount of carbon stored in trees, ${ }^{2}$ wood products, ${ }^{3}$ and soils of forest plantations in a dynamic fashion. ${ }^{4}$ Since there is insufficient land for both food production and forest plantation in developing countries with high population densities such as China, agroforestry appears to be a good means to meet food and energy demands, as well as global environmental constraints. Zhao ${ }^{5}$ reported that shelterbelt systems in the North China Plain reduced wind speed by $20-40 \%$ and thereby improved surface soil moisture by $13 \%$. As a result of agroforestry practices, the crop yields in the agroforestry systems were increased by $2.5-30 \%$ for wheat (Triticum aestium) and by $9.6-21 \%$ for maize (Zea mays). Nonetheless, few studies have tackled the carbon-storage problem of the agroforestry systems. ${ }^{6.7}$ Further research on treecrop improvement and site-species trials is necessary before large scale deployment. In this paper, the potentials of different options of agroforestry systems for storing carbon have been evaluated.

\section{BACKGROUND OF THE EXPERIMENTAL SITES}

Our experimental sites are located in the vicinity of the Pandian Agricultural Ecological Experimental Station $\left(35.1^{\circ} \mathrm{N}, 114.5^{\circ} \mathrm{E}\right.$ ) in Fengqiu County, Henan Province, which falls within the Yellow River and Hai River Basins. Soils are comprised of river sediments interspersed with poor, sandy, saline soils. The land is level, with low elevation. The fields can easily be irrigated. The climate belongs to the temperate, continental monsoon type and is characterized by frequent occurrences of drought, dry-hot wind, hail, frostbite, and sand storms. Severe climate and saline land restrict biomass productivity.

\section{STRUCTURE FOR THE AGROFORESTRY SYSTEMS AT THE EXPERIMENTAL SITES}

The agroforestry systems consist of trees and crops. Proper selection of tree and crop species and their rational temporal and spatial arrangements are crucial so that the efficiencies of utilization of solar radiation, water and nutrients can be high. Poplar (Paplus canadensis) and paulownia (Paulownia elongata) were chosen because the projection areas of their canopies are relatively small, and they grow well in the local saline soils. Wheat and maize are the two crops harvested each year from the same plots. The temporal arrangements of crops and plantations were such that wheat was harvested 
Table 1. The structure of two agroforestry systems: shelterbelt and intercropping plantation in the North China Plain.

\begin{tabular}{lcc}
\hline Item & Shelterbelt type & Intercropping type \\
\hline Species of trees & Poplus canadensis & Paulowania elongata \\
Species of crops & Triticum aestium & Zea mays \\
& Zea mays & 0.1 \\
Land area occupied by trees $(\%)$ & 2.5 & 1 \\
Distance between treebelts $(\mathrm{m})$ & $200-300$ & 40 \\
Number of rows in each belt & 3 & 5 \\
Spacing between rows $(\mathrm{m})$ & 5 & 50 \\
Spacing between trees $(\mathrm{m})$ & 4 & 15.6 \\
Platnation density of trees (trees/ha) & & \\
\hline
\end{tabular}

early in May before the leaves of the trees became dense enough to affect the crop productivity. Maize planting between rows of wheat was completed in April before the wheat havest.

Table 1 gives the layout of our two types of agroforestry systems. In the shelterbelt type, poplar grew along the boundaries of crop plots. Each land plot is $200 \mathrm{~m} \times 300 \mathrm{~m}$. The treebelt consists of three rows of trees at $5 \mathrm{~m}$ spacings between rows of each belt, and $4 \mathrm{~m}$ spacings between trees in each row. In the intercropping system, paulownia trees were planted in the crop land on a space $40 \mathrm{~m} \times 5 \mathrm{~m}$. As may be seen from Table 1 , trees occupy only $0.1-2.5 \%$ of the total land area of the agroforestry systems.

\section{BIOMASS PRODUCTIVITY}

The growth parameters of poplar and paulownia in our experimental plots were measured (Table 2). Then the biomass in living trees was calculated using the allometric formulae listed in Table $3,^{8-10}$ which hold for plantations growing on similar sites in China. The differences between the final and initial biomass, which were recorded in September and April annually, were taken as the productivities of trees in the agroforestry systems.

The crop productivity was measured by use of the quadrate-harvest method. Since crops are annual plants, their biomass equals their productivity.

The total productivity of agroforestry systems is the sum of tree and crop productivities. From Table

Table 2. The growth parameters of 6-year old poplar and paulownia in agroforestry systems in the North China Plain.

\begin{tabular}{lcc}
\hline Item & Shelterbelt type & Intercropping type \\
\hline Initial† mean height $(\mathrm{m})$ & 14.4 & 9.6 \\
Initial† mean DBH $(\mathrm{cm})$ & 20.1 & 22.6 \\
Final† mean height $(\mathrm{m})$ & 15.3 & 11.0 \\
Finalł mean DBH $(\mathrm{cm})$ & 22.3 & 25.4 \\
\hline
\end{tabular}

$\dagger$ Measured at the beginning of each growing period in April.

¥Measured at the end of each growing period in September.

Table 3. The allometric formulae for estimating biomass and volume of poplar and paulownia in the agroforestry systems.

\begin{tabular}{|c|c|c|c|c|}
\hline Species & Item & Equation & $\begin{array}{l}\text { Correlative } \\
\text { coefficient }\end{array}$ & Reference \\
\hline Poplus canadensis & $\begin{array}{l}\text { Total biomass } \\
\text { Volume }\end{array}$ & $\begin{array}{l}\log (W)=2.31081 \times \log (D)-0.74787 \\
V=0.00006568 \times D^{1.041} H^{0.844} \\
H=3.1392 \times D^{0.5312}\end{array}$ & $\frac{0.992}{-}$ & $\begin{array}{l}5 \\
6\end{array}$ \\
\hline Paulownia elongata & $\begin{array}{l}\text { Total biomass } \\
\text { Volume }\end{array}$ & $\begin{array}{l}W=0.174401 \times D^{2.0776065} \\
V=0.0014 \times D^{2.255029}\end{array}$ & $\begin{array}{l}0.992 \\
0.997\end{array}$ & $\begin{array}{l}7 \\
7\end{array}$ \\
\hline
\end{tabular}


Table 4. Comparisons of biomass, productivity and carbon absorption for the two typical agroforestry systems with those of a control agricultural system in the North China Plain.

\begin{tabular}{|c|c|c|c|}
\hline Items & Shelterbelt type & Intercropping type & Control agriculture \\
\hline Initial $\dagger$ tree biomass (ton $/ \mathrm{ha}$ ) & 3.99 & 5.73 & \\
\hline Final $\neq$ tree biomass (ton $/$ ha) & 5.57 & 7.37 & \\
\hline Tree productivity (ton/ha/yr) & 1.58 & 1.64 & \\
\hline Crop productivity§ (ton/ha/yr) & 28.58 & 27.60 & 25.70 \\
\hline Total productivity (ton $/ \mathrm{ha} / \mathrm{yr}$ ) & 30.16 & 29.24 & 25.70 \\
\hline Initial $\uparrow$ carbon storage of trees (ton $\mathrm{C} / \mathrm{ha}$ ) & 2.00 & 2.87 & \\
\hline Final $\ddagger$ carbon storage of trees (ton $\mathrm{C} / \mathrm{ha}$ ) & 2.79 & 3.69 & \\
\hline Net carbon absorbed by trees (ton $\mathrm{C} / \mathrm{ha} / \mathrm{yr}$ ) & 0.79 & 082 & 0 \\
\hline
\end{tabular}

$\dagger$ Measured at the beginning of each growing period in April.

$\ddagger$ Measured at the end of growing period in September.

\$The sum of two crop harvests: wheat harvest in May and maize harvest in September.

TThe sum of crop and tree productivities.

4, we see that the agroforestry systems had increased crop productivities over the control agricultural system. These increments in crop productivity may be attributed to proper spatial and temporal arrangements of planting.

\section{ESTIMATION OF CARBON STORAGE IN AGROFORESTRY SYSTEMS DURING A COMPLETE ROTATION PERIOD}

The amount of carbon in trees varies with their age. The rotation length defines the total amount of accumulated carbon. According to our previous investigation, the optimal rotation period for poplar and paulownia on the North China Plain has been found to be 10 years. Consequently, the DBH (Diameter at Breast Height) at an age of 10 years was estimated numerically by extrapolation, using the data in Table 5. ${ }^{11,12}$

Accumulated stemwood volumes were calculated using allometric formulae listed in Table 3 . The volumes were then converted to carbon mass as follows:

$$
\text { carbon mass }=\text { volume } \times \text { stemwood density } \times f_{\mathrm{c}} \text {, }
$$

where $f_{\mathrm{c}}=0.5$ is the mean fraction of carbon in dry biomass, and a stemwood density of 0.5 was adopted.

Stemwood was harvested for wood products (packaging, fiberboard, furniture, building timber, etc.). Wood from fast growing plantations such as poplar tends to be used for inferior products with shorter lifetimes. The exact lifetimes of wood products are poorly known, but a reasonable assumption is that

Table 5. Changes in the diameter at breast height (DBH) of poplar and paulownia in the agroforestry systems.

\begin{tabular}{ccc}
\hline & \multicolumn{2}{c}{ Diameter at breast height $(\mathrm{DBH})(\mathrm{cm})$} \\
\cline { 2 - 3 } Age (years) & Poplar canadensis & Paulownia elongata \\
\hline & 4.8 & 4.0 \\
2 & 9.1 & 6.0 \\
3 & 14.8 & 10.5 \\
4 & 18.5 & 17.1 \\
5 & 20.1 & 20.1 \\
6 & 22.6 & 22.5 \\
7 & 25.6 & 26.7 \\
8 & 27.8 & 30.0 \\
9 & 29.5 & 33.0 \\
10 & 31.8 & 35.9 \\
\hline
\end{tabular}


Table 6. The total biomass, stemwood and carbon storage for a complete rotation of 10 years in the two typical agroforestry systems in the North China Plain.

\begin{tabular}{lcr}
\hline Items & $\begin{array}{c}\text { Shelterbelt } \\
\text { type }\end{array}$ & $\begin{array}{c}\text { Intercropping } \\
\text { type }\end{array}$ \\
\hline Total biomass (ton/ha) & 8.34 & 14.44 \\
Carbon fixation (ton C/ha) & 4.17 & 7.22 \\
Stemwood volume ( $\left.{ }^{3} / \mathrm{ha}\right)$ & 10.64 & 15.72 \\
Stemwood weight (ton/ha) & 5.53 & 8.17 \\
Carbon storage in timber for long-term period (ton C/ha) & 1.16 & 1.72 \\
Heat emitted from biomass burning (10 $\mathrm{J} / \mathrm{ha})$ & 108.2 & 198.2 \\
Carbon equivalent to the heat from coal (ton C/ha) & 1.82 & 3.33 \\
Total carbon sequestered in 10 years (ton C/ha) & 2.34 & 5.05 \\
\hline
\end{tabular}

wood product lifetimes in China are at least equal to the rotation lengths. The proportion of stemwood used as long-lived wood products is estimated to be $42 \%$. Therefore,

long-lived carbon storage $=$ carbon mass in stemwood $\times 42 \%$.

It is assumed that short-lived biomass will be used as fuel to replace fossil fuels. The weight of biomass fuel equals the total biomass weight minus the long-lived stemwood weight. Since the heat released per unit weight of biomass is taken as $18 \times 10^{9} \mathrm{~J} /$ ton,

$$
\text { heat from biomass combustion }=[\text { biomass }-(\text { stemwood weight } \times 0.42)] \times 18 \times 10^{9} \text {. }
$$

The thermal efficiency of biomass combustion is only $60 \%$ of that achieved with fossil fuels. ${ }^{1}$ If the heat release from combustion of unit weight of coal is taken as $25 \times 10^{6} \mathrm{~J} /$ ton and the carbon content of coal is $70 \%$, then,

carbon storage from coal substitution $=($ heat of biomass combustion $\times 0.60 \times 0.70) /\left(25 \times 10^{9}\right)$.

The total amount of carbon sequestered in the agroforestry systems is the sum of the long-lived carbon storage in wood products and the carbon storage due to substituting biomass for coal. The results of our estimation are listed in Table 6. The total reduction in $\mathrm{CO}_{2}$ emission is 0.23 ton $\mathrm{C} / \mathrm{ha} / \mathrm{yr}$ and 0.50 ton $\mathrm{C} / \mathrm{ha} / \mathrm{yr}$ for shelterbelt and intercropping plantations, respectively.

\section{COST AND BENEFIT ANALYSES}

The costs of planting and management and the benefits from wood and crop harvests for a complete rotation period of 10 years are listed in Table 7 . As may be seen from Table 7, the cost increment of the agroforestry systems is very small compared to that of the control agricultural systems, while the benefits are significant.

Table 7. Cost-benefit analysis for a 10-year rotation period.

\begin{tabular}{lccc}
\hline Items & $\begin{array}{c}\text { Shelterbelt } \\
\text { type }\end{array}$ & $\begin{array}{c}\text { Intercropping } \\
\text { type }\end{array}$ & $\begin{array}{c}\text { Control } \\
\text { agriculture }\end{array}$ \\
\hline Establishing cost (RMB/ha) & 145 & 464 & \\
Management cost (thousand RMB/ha) & 50.1 & 52.1 & 51.4 \\
Benefit (thousand RMB/ha) & 214.5 & 266.3 & 185.8 \\
Revenue (thousand RMB/ha) & 164.3 & 213.8 & 134.4 \\
\hline
\end{tabular}




\section{DISCUSSION}

We have noted that agroforestry systems play an important role in improving the environment and enhancing crop productivity. There are now more than 1 million hectares of farmland shelterbelt and 2 million hectares of tree-crop mixed plantations in China. ${ }^{13}$ According to our estimation, the rate of reduction of $\mathrm{CO}_{2}$ emissions into the atmosphere is 0.23 ton $\mathrm{C} / \mathrm{ha} / \mathrm{yr}$ for shelterbelt and 0.50 ton $\mathrm{C} / \mathrm{ha} / \mathrm{yr}$ for intercropping systems, respectively. Agroforestry systems in China can sequester about $1.23 \times 10^{6}$ ton $\mathrm{C} / \mathrm{yr}$, which is $0.16 \%$ of the carbon release from fossil-fuel combustion and cement production $\left(0.76 \times 10^{9}\right.$ ton $\left.\mathrm{C} / \mathrm{yr}\right)$. There are two current national projects: the East Plain Forestry System and the "Three North's" (North East, North China and North West) Forest Protection System. The arable land in the eastern part of China is estimated to be 47 million ha. ${ }^{14}$ If we assume that $50 \%$ of this land is constructed as tree-crop-mixed plantations and $50 \%$ as farmland shelterbelt, the amount of carbon absorbed from the atmosphere by agroforestry in the East Plain Forestry System will be $17.16 \times 10^{6}$ ton $\mathrm{C} / \mathrm{yr}$. About 35.08 million ha of land in the "Three North's" Forestry Protection project will be planted. ${ }^{15}$ The amount of carbon absorbed from the atmosphere will then be $8.07 \times 10^{6}$ ton $\mathrm{C} / \mathrm{yr}$. The two projects will sequester $25.23 \times 10^{6}$ ton $\mathrm{C} / \mathrm{yr}$, which is $3.3 \%$ of the carbon release from fossil-fuel combustion and cement production in China.

Acknowledgements-We thank Professor Ya-Hui Zhuang for his review and comments on this paper. This work is funded by National Natural Science Foundation of China under Contract No. 390011.

\section{REFERENCES}

1. G. Marland and S. Marland, Water Air Soil Pollut. 64, 181 (1992).

2. P. Schroeder and L. Lodd, Climate Change 19, 283 (1991).

3. D. Thompson and R. Matthews, Forestry and British Timber 18, 19 (1989).

4. R. C. Dewar and M. G. R. Cannell, Tree Physiology 11, 49 (1992).

5. T. Zhao and Q. Lu, Agroforestry Today 5, 2 (1993).

6. K. F. S. King, in Agroforestry: a Decade of Development, pp. 3-12, H. A. Steppler and P. K. N. Nair eds., International Council for Research in Agroforestry (ICRAF), Nairobi, Kenya (1988).

7. Z. Feng, X. Wang, G. Wu, and G. Liu, Structure and Function of Agroforestry Systems: a Case Study in North Henan Province, China, China Science and Technology Publishing House, Beijing (1992).

8. Q. S. Zhao, Rural Ecol. Environ. 11, 1 (1989).

9. Forestry Survey, Planning and Designing Institution, Forestry Survey Tables, Chinese Forestry Press, Beijing (1988).

10. X. Yang, J. Henan Agr. Univ. 20, 485 (1986).

11. Q. Han and S. Lu, J. Nanjing Forestry Product Industry 12, 60 (1983).

12. Y. Chen, Paulownia Res. 2, 6 (1989).

13. Z. Zhu, M. Fu, and C. B. Sastry, in Agroforestry Systems in China, pp. 2-7, Z. Zhu, ed., The Chinese Academy of Forestry and International Development Research Center, Canada, Beijing (1991).

14. China Natural Resource Handbook Editorial Board, China Natural Resource Handbook, Academic Press, Beijing (1991).

15. W. Liu and Q. Pang, in Agroforestry Systems in China, pp. 118-123, Z. Zhu ed., The Chinese Academy of Forestry and International Development Research Center, Canada, Beijing (1991). 